ISSN: 2224-0616

Int. J . Agril. Res. Innov. Tech. 8 (2): 54-60, December 2018

DOI: https://doi.org/ 10.3329/ijarit.v8i2.40556

Available online at https://ijarit.webs.com https:// www.banglajol.info/index.php/ IJ ARIT

\title{
DETERMINANTS OF AGRICULTURAL PRODUCT EXPORT: EVIDENCE FROM A PANEL DATA ANALYSIS OF EAST AFRICAN COUNTRIES
}

\section{Leta ${ }^{*}$ and B.B. Tegegn ${ }^{2}$}

\begin{abstract}
Only 6 East African countries and 15 years (1996-2010) macroeconomic data was considered due limitation of data availability. Secondary data sources was used and necessary data were collected from the World Bank Development Indicator, Food and Agricultural Organization of the United State, and International Monetary fund base line data. Both descriptive and econometric models were employed. A Demand and Supply Linear Model was employed for the analysis. The selection test result confirmed that random effect to be an appropriate model for the analysis. Findings of the study revealed that the supply side of Agricultural Product Export were found to be statistically significant at $\mathrm{P}<0.01$ level, while the demand side Ln Growth Domestic Product of China variables was found to be statistically significant at $\mathrm{P}<0.01$.
\end{abstract}

Keywords: East Africa, Agricultural Product, Export, Panel, Data

${ }^{1} \mathrm{PhD}$ Fellow, Department of Agricultural Economics, College of Agriculture and Environmental Science, Haramaya University, Ethiopia

${ }^{2}$ Assistant Professor, Department of Agricultural Economics, College of Agriculture and Environmental Science, Haramaya University, Ethiopia.

*Corresponding author's email: leta4mijena@gmail.com (M. Leta)

Cite this article as: Leta, M. and Tegegn, B.B. (2018). Determinants of agricultural product export: evidence from a panel data analysis of East African countries. Int. J. Agril. Res. Innov. Tech. 18(2), 54-60.

\section{Introduction}

Agricultural commodity trade has played a prominent role in Africa's economic development. As suppliers of raw materials to western economies, African countries have continued to produce primarily crops for export. Thus, the agricultural exports sector is still the most important single activity for Africans (Amoro and Shen, 2013). In Sub-Saharan Africa (SSA), about 75 percent of people live in rural areas, and almost all of them depend on agriculture for their livelihoods. Agriculture accounts for 40 percent of gross domestic product (GDP), 15 percent of exports, and 60 - 80 percent of employment. Agriculture therefore remains highly important for sustainable development and poverty reduction, as well as a source for livelihood, economic growth, and provider of environmental services (World Bank, 2005).

Support to the agricultural sector, however, as not been commensurate with its importance. Since 1980, agricultural spending as a share of total spending in Africa ranged from 4 to 6 percent in the aggregate, which has led to general stagnation (Omilola et al., 2010; Dramé - Yayé et al., 2011). More so, African agricultural production is largely subsistence in nature with a high dependence on the rain; farmers suffer price competition with large-scale farmers in more developed countries who flood their products in Africa while export capacity of locally produced agricultural products from Africa is very limited (Mkpado, 2013).

FAO (2011) observed that the distribution of available arable land in the world indicates that sub Saharan Africa 1031 million ha, has made the region the $1^{\text {st }}$ position of Africa in arable land distribution which shows great potential Africa has in agricultural production. Export markets for African agricultural products include United States of America (USA), European Union, Gulf States, J apan, Singapore and China.

According to IMF (2010) if greater market access is granted by industrial countries to Africa's product, real incomes in SSA would increase by USD 6 per person and reduces the number of people living in poverty by as much as $13 \%$ by the year 2015. Moreover, Gbetnkon and Khan (2002) find hat the impact of $1 \%$ increase in OECD real income growth results in primary export demanded by $1.6 \%$. 


\section{Statement of the problem}

Agriculture remains the main export-revenue source for many African countries and the largest income generator for their population (World Bank, 2007). The region's share of global agricultural export has declined gradually from almost $10 \%$ four decades ago to around 3\% today. On the import side, the opposite pattern emerges as Sub-Saharan Africa is the only developing-country region that has seen its share of world agricultural imports increase rather than decrease (Bacchetta, 2007; World Bank, 2007; and Christiaensen, 2004).

Many research findings so far undertaken on agricultural product export came about with of price competitiveness measures, which tend to be relatively small, which translates into a slow adjustment of export volumes to relative price developments. The cause of poor export performance in agricultural sector, especially in East African countries could have been attributed to poor domestic policies as well as restrictive policies pursued by developed countries related with tariffs and non tariffs. Moreover, the region to increase its agricultural product exports conceived as constrained by its economic level, infrastructure and institutional barriers, its ability to diversify Export, issues related to exchange rate and contrary agricultural development policies set by developed countries. Thus. This research work was set about doing to examine factors other than price competitiveness on agricultural product export performance of East African counties.

\section{Objectives}

\section{General objective}

The main objective of this research work is to examine empirically the determinants of East African countries agricultural export.

Specific objectives

The specific objects of the research work was set forth of making an effort:

- To examine the relative importance of the two major factors of demand and supply in determining the country's agricultural export performance.

- To describe the relative position of East African countries' Agricultural product export performance.

\section{Methodology}

Study to examine the determinants of Agricultural product export of six East African countries entails employing the panel data. Random effects estimation technique was used as a method of data analysis. Using panel technique over time series analysis is due to its advantage that panel technique has the ability to control the individual heterogeneity and measure the effects that are simply not detectable in pure time series data. Additionally, panel technique allows us to construct and test more complicated models than in time series (Marno, 2004; Baltagi, 2005), and it isalso considered to be more informative as compared to time series data. Panel technique variables are less collinear than in time series, as such panel technique has more degree of freedom and it is more efficient than time series data (Marno, 2004).

\section{Descriptiveanalysis}

Descriptive statistics are statistics that quantitatively describe or summarize features of a collection of information with the help of measures of central tendency and measures of variability or dispersion. Measures of central tendency include the mean, median and mode, while measures of variability include the standard deviation (or variance), the minimum and maximum values. Thus, the second objective of this seminar would be described using the descriptive analysis.

\section{Econometric model and Model Specification}

\section{Model specification}

Determinant of agricultural product export of East African country i can be expressed using the general form of linear panel regression model as specified bellow:

$\left.\mathrm{AGEX}_{i t}=\alpha_{i}+\beta X_{i t},+u_{i t}, i=1,2, . ., N t=1,2, \ldots, T . . .1\right)$

Where, $u_{i t}=\mu_{\text {it }}+\varepsilon_{\text {it }}$

The vector $\beta$ is a constant vector of parameters; $\mu_{\mathrm{it}}$ denotes the unobservable individual specific effects which are time invariant and account for any individual-specific effects not included in X; i subscript denotes is a scalar the cross-section dimension and $t$ denotes the time series dimension, $\varepsilon_{i t}$ is the usual error component which is assumed to be IID (o, 62) (Baltagi, 2005).

AGEX $_{\text {it }}$ represents Total Agricultural Product Export of East African country $\mathbf{i}$ at period $t$ (in million USD). $\mathrm{X}_{\mathrm{it}}$ represents a vector of (logs of) the following explanatory variables:

$\mathrm{GDP}_{\mathrm{it}}=$ GDP (billiom USD) of the exporting a countries at timet,

GDPIMjt= GDP (bil. USD) of major trading partnersj (US, China and EU) at timet,

REER $_{\text {it }}=$ Real Effective Exchange Rate expressed (\% GDP) of a country i at time $t$,

$\mathrm{OPENN}_{\mathrm{it}}=$ Openneness (ratio of Export +Import/GDP) at time t,

$\mathrm{FDI}_{\mathrm{it}}=\mathrm{FDI}$ inflow (\%GDP) of country $i$ at time $\mathrm{t}$, EXDIV $_{\mathrm{jt}}=$ Export Diversification Index of a country i at time t,

LANDLK dummy= land lockedness of country I. It is dummy takes value 0 if the country is land locked 1 , otherwise 0 . 
Data and explanation of variables

Data source

Among the Eighteen East African countries, only six countries viz. Burundi, Comoros, Kenya, Mauritius, Rwanda, and Uganda were considered for this research work. The basic reason is that required data from baseline data of IMF, FAO and World bank development indicators could not be available for the omitted East African countries. Effective real Exchange rate was taken from World Bank http:// www.bruegel.org/publications/ publication -detail/publication/716-real-effective-exchangerates-for-178-countries-a-new-database/ accessed on 12/02/2017. Foreign direct Investment, Export Diversification, and Trade openness of countries were obtained from world development indicator database.

\section{Explanation of Variables}

The dependent Variable, AGEX $\mathrm{X}_{\mathrm{it}}$ (million US Dollar) is the total Agricultural Product export of each of six East African countries for the period 1996-2010.

i. GDP of the exporting country (GDP $\left.{ }_{i t}\right)$ : According to Eyayu (2011) the size of the exporting and importing countries which is represented by GDP is a basic determinant in explaining exports.

ii. GDP of the importing country

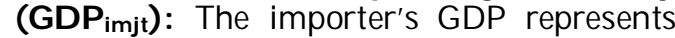
potential demand or absorptive capacity of East African country i agricultural product export.

iii. Real Effective Exchange Rate (REERit): It is a trade - weighted geometric average of the level of consumer prices in home country relative to that in its trading partners.

iv. Openness $\left(\mathbf{O P E N N}_{\mathrm{it}}\right)$ : The simple measure of trade policy reform is the ratio of export (X) plus import (M) to GDP, often referred to as measure of openness or trade dependence index.

v. Foreign Direct Investment (FDI $\left.{ }_{i t}\right)$ : experessed as a (\% GDP). Following the liberalization processes that began in early 1990s, SSA countries opened their markets and have been encouraging foreign investment in abroad range of sectors including agriculture (Kumar and Pradhan, 2002).

vi. Export Diversification Index (DIVER $\mathrm{R}_{\mathrm{it}}$ ): Greater diversification of the productive structure would imply, ceteris paribus, more higher-value added activities of a country dedicated to the export of agricultural commodities, and adds more to the volume of exports.

vii. Landlockdness (LANDLK it $_{\text {t): }}$ The essence of the variable is to capture if being a land locked economy can adversely affect export growth.

Model estimation techniques

Spatial units variable which are usually spacespecific, time-invariant that do affect the dependent variable but are difficult to measure or hard to obtain has to be accounted in the model by introducing a variable intercept $\boldsymbol{\mu}_{\mathbf{i}}$ representing the effect of the omitted variables that are peculiar to each spatial unit considered (Lee, 2001). Fixed effects and random effects models work to remove omitted variable bias by measuring change within a group.

\section{Fixed effects model}

Fixed effects model would be employed for controlling unobserved heterogeneity when heterogeneity is constant over time and correlated with independent variables. If there are omitted variables, and these variables are correlated with the variables in the model, then fixed effects models may provide a means for controlling for omitted variable bias.

$\mathrm{y}_{\mathrm{it}}=\beta_{0}+\beta \mathrm{X}_{\mathrm{it}}+\gamma \mathrm{Z}_{\mathrm{i}}+\alpha_{\mathrm{i}}+\mathrm{u}_{\mathrm{it}} \ldots$ (3)

Where: $Y_{i t}$ is the dependent variable observed for individual $\mathrm{i}$ in time $t$.

$\mathrm{X}_{\mathrm{it}}$ is the time-variant regressor,

$\mathrm{Z}_{\mathrm{i}}$ is the time-invariant regressor; observed and can not be estimated directly by the fixed effect model but can be estimated by the random effect model

$\alpha_{i}$ is the unobserved individual effect

$u_{i t}$ is the error term, and $\beta_{0}, \beta$, and $\gamma$ are Parameters to be estimated.

Random effects model

Random effects model also called "variance components" assume that the entity's or individual's error term is not correlated with the predictors which allows for time-invariant variables to play a role as explanatory variables. If an effect is assumed to be a realized value of a random variable, it is called a random effect (LaMotte, 1983). The feasible generalized least squares method known as random-effects regression (Wooldridge, 2002) is indicated below.

$\mathrm{y}_{\text {it }}=\beta \mathrm{X}_{\mathrm{it}}+\alpha+\mathrm{u}_{\mathrm{it}}+\varepsilon_{\mathrm{it}}$

Where;

$y_{i t}$ is the dependent variable observed for individual $i$ in time $t$.

$\mathrm{X}_{\mathrm{it}}$ is the time-variant regressor,

$\alpha$ is the unobserved individual effect

$u_{i t}$ is the error term between entity, $\varepsilon_{\mathrm{it}}$ is the error term with in entity 


\section{Random effects model}

Among the three alternatives model, appropriate model should be selected based on commonly followed selection test criteria.

Model selection between Random effects and pooled effect model

The testing for random effect or Pooled effect is conducted based on Breusch-Pagan Lagrange multiplier (LM) test. The hypothesis is:

HO: Variances across entities (countries) is zero (homoscedastic).

HA: Variances across entities (countries) is not zero.

Based on test statistical result, if the null hypothesis is not rejected $5 \%$ level the pooled effect model would be appropriate, and therefore, run a simple OLS regression.

Model selection between random effects and fixed effect model

The testing for random effect or fixed effect is conducted based on Hausman (1978) test. To decide between fixed or random effects, the choice would be made based on the Hausman specification selection test where the null hypothesis is that the preferred model is random effects vs. the alternative the fixed effects (Green and Tukey, 1960). It basically tests whether the unique errors $\left(\mathrm{u}_{\mathrm{i}}\right)$ are correlated with the regressors, the null hypothesis is they are not (Green and Tukey, 1960). The random effects model is: The hypothesis is: It basically tests whether the unique errors $\left(\mathrm{u}_{\mathrm{i}}\right)$ are correlated with the regressors. The test hypothesis is specified as:

Ho: difference in coefficients not systematic HA: difference in coefficients not systematic

Based on test statistical result, if the null hypothesis is rejected at $5 \%$ level, fixed effect model would be appropriate model.

\section{Unit root test}

Before the estimation of panel data the univariate characteristics of the variables should have been tested for panel unit root. This is the first step in determining a potentially cointegrated relationship between the variables. If all variables are stationary, then the traditional estimation OLS can be used to estimate the relationship between variables. If they contain a unit root or are nonstationary, a cointegration test should be performed. Thus, this research work applied panel unit root tests using the LLC method (Levin et al., 2002). The LLC test assumes that the autoregressive parameters are common across sections. The null hypothesis of a unit root is stated as:
H0: Panels are non-stationary (autoregressive parameter is constant across panels)

HA: Panels are stationary

\section{Results and Discussion}

\section{Descriptive analysis}

The second objectives of this research work were addressed using descriptive analysis. The six East African countries relative agricultural product export performance (in million \$) for the time 1996 to 2010 was illustrated by the graph 1 below. Among East African countries, Kenya is the most exporter of agricultural product. It has shown significant increase since 2002, and reached above 1,500,000 million \$ since 2007. Uganda Follows Kenya since 2006 and reached above 500,000 million \$ since 2007. Comoros, Burund, and Rwanda are among the least agricultural product exporters, and all of these country's export is below 500000 million \$. Mauritius Agricultural product export performance shows a steady decreasing pattern throughout the whole periods examined and becomes below 500,000 million \$ since 1996.

Agricultural product exported by the six East African countries varied between the minimum of 1,123 (mill \$) and a maximum of 1,808,296 (mill \$); while the average agricultural product exported for each year (1996 to 2010) varied between 244,127.3 (mill \$) 506,997 (mill \$). But the agricultural product exported for the within six African countries varied between -146,259.5 (mill \$); and 1,647,021 (mill \$). The negative sign indicates, which is not to say that any country actually Export negative amount. The within number refers to the deviation from each individual's average, and naturally, some of those deviations must be negative. In a similar argument the GDP of importing of six East African countries varied between the minimum of 79.75 (bill \$) and a maximum of 30,253.06 (bill \$); the average GDP of these exporting East African countries for each year (1996 to 2010) varied between the minimum 926.14 (bill \$) and a maximum of 6,508.76 (bill \$), and GDP for the within six African countries varied between 3,360.96 (bill \$) 26,690.27 (bill \$).

\section{Econometric model and specification}

Testing for random effects: Breusch-Pagan Lagrange multiplier (LM)

The LM test helps you decide between a random effects regression and a simple OLS regression. The test hypothesis is specified as:

HO: Variances across entities (countries) is zero (homoscedastic).

HA: Variances across entities (countries) is not zero. 
Table 1. Breusch and Pagan Lagrangian multiplier test result for random effects model .

\begin{tabular}{|ccc|}
\hline Estimated results & Var & sd = sqrt(Var) \\
\hline LnAGREX & 3.242134 & 1.800593 \\
\hline $\mathrm{e}$ & 0.2183635 & 0.4672938 \\
\hline $\mathrm{u}$ & 90865 \\
\hline chibar2 $(01)=3.26$ & Prob $>$ chibar2 $=0.077$ & 301.4382 \\
\hline
\end{tabular}

Source: Own calculation result

Hausman test for fixed or random effects model Selection

HO: Errors (ui) are correlated with the regressors; preferred model is random effects

To decide between fixed or random effects a Hausman test would be employed. The test HA: Errors (ui) are not correlated with the hypothesis is as follows:

Table 2. Hausman fixed or random effect model selection test result.

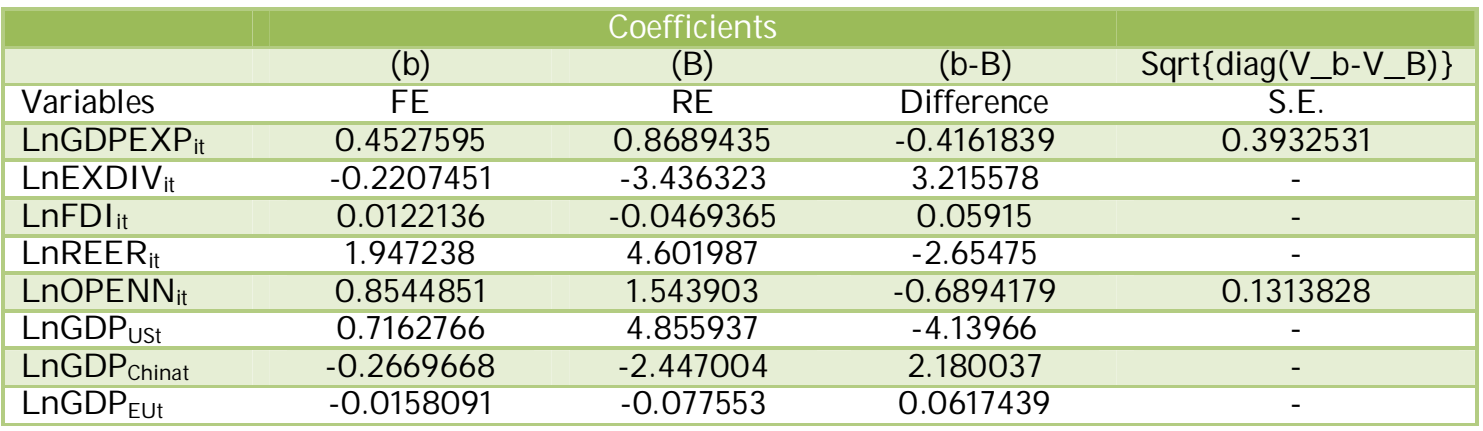

$\mathrm{b}=$ Consistent under Ho and Ha; obtained from; $\mathrm{B}$, inconsistent under Ha, efficient under Ho

Test: Ho: differencein coefficients not systematic

$\operatorname{chi}^{2}(8)=(b-B)^{\prime}\left[\left(\mathrm{V} \quad b-V_{-} B\right)^{\wedge}(-1)\right](b-B)$

$=-31.30 \mathrm{chi}^{2}<0$

Based on the Hausman specification test result, $\mathrm{HO}$ would be rejected for the chi ${ }^{2}$ is insignificant. Statistical test result of the three models: Fixed effect, Random effect and pooled effect model was presented by Table 2 below. The first and second objective of this research was explained based on the result of random effect model. Accordingly, from the supply side of LnGDPEXP $_{\text {it, }}$ LnEXDIV $_{\text {it, }}$ LnREER $_{\text {it }}$, LnOPENN it $_{\text {it }}$ were found to be statistically significant at $\mathrm{P}<$ 0.01 level, while from the demand side, LnGDP $_{\text {Chinat }}$ variables was found to be statistically significant at $\mathrm{P}<0.01$ This implies that a 1 unit increase in LnGDPEXP it, $_{\text {, }}$ LnREER $_{\text {it }}$ and LnGDP $_{\text {Chinat }}$ variables, holding constant for other variables, the LnAGREX $X_{i}$ changes by 0.850 , 2.342, 0.885 units, respectively. However, for 1 unit increase in LnEXDIV it $_{\text {it }}$ variable, holding constant for other variables, the LnAGREX decreases by 0.364 unit. On the other hand, $\mathrm{LnFDI}_{\text {it }}$ and LnLANDLK $\mathrm{i}_{\mathrm{it}}$ were found to be statistically significant at $\mathrm{P}<0.05 ; \quad$ LnAGREX $_{i}$ increase by 0.015 units for a 1 unit increase in LnOPENN $_{\text {it, }}$ but LnAGREX ${ }_{i}$ decreases by 1.814 unit for a 1 unit increase in LnLANDLK holding constant for other variables.

\section{Estimation Techniques}

Unit root test

The LLC test result indicates that all explanatory variables were found to be statistically significant

at $\rho<1 \%$. Implying that rejection of the null hypothesis Panels contain unit roots. So, the panel data are stationary.

Testing for cross -sectional dependence/ contemporaneous correlation (Pasaran CD test)

According to Baltagi (2008), cross - sectional dependence is a problem in macro panels with long time series. B- P/LM and Pasaran CD (cross -sectional dependence) tests are used to test whether the residuals are correlated across entities. The test hypothesis for cross sectional independence according to Pasaran CD is stated as: Considering to the panel model (4) above,

$$
\mathrm{y}_{\mathrm{it}}=\beta_{1}+\beta^{\prime} \mathrm{x}_{\mathrm{kit}}+v_{\mathrm{it}}
$$

Where: $\mathrm{x}_{\mathrm{it}}$ and $\beta$ are a $\mathrm{K} \times 1$ vector of regressors and vector of parameters to be estimated respectively. $\quad \alpha_{i}$ represent time-invariant individual parameters. Under the null hypothesis $\mathrm{u}_{\mathrm{it}}$ is assumed to be independent and identically distributed (i.i.d.) over time-periods and across cross-sectional units. Under the alternative, $u_{i t}$ may be correlated across cross-sections but the assumption of no serial-correlation remains. Thus, the hypothesis of interest is

$\mathrm{H}_{0}: \rho_{\mathrm{ij}}=\rho_{\mathrm{ji}}=\operatorname{cor}\left(\mathrm{u}_{\mathrm{it}}, \mathrm{u}_{\mathrm{j} t}\right)=0$ for $\mathrm{i} \neq \mathrm{j}$ (Residuals across entities Countries are not correlated $\mathrm{H}_{1}: \rho_{\mathrm{ij}}=\rho_{\mathrm{ji}} \neq 0$ for some $\mathrm{i} \neq \mathrm{j}$ (Residuals across entities Countries are correlated. 
Table 4. Cross -sectional dependence (Peseran CD ) test result.

\begin{tabular}{|lc|}
\hline Test & Peseran CD \\
\hline Cross sectional independence & $0.296(0.7674)$
\end{tabular}

Source: Own computation

As the test result shows, there is strong statistical evidence to accept the null hypothesis. This indicates that Residuals across entities Countries are not correlated.

\section{Conclusion and Recommendation}

Agricultural product export is believed to have a significant contribution for African economy in enhancing the source of foreign currency from the export of semi processed and raw materials. The major objective of this seminar is to examine the determinants of East African countries agricultural product export. Due limitation of data availability, only 6 East African countries, and 15 years from 1996-2010 of macroeconomic data was considered. Secondary data sources from the World Bank Development Indicator (WDI), FAO and IMF base line data was collected. Both descriptive and econometric models were employed.

In order to capture determinants of East Africa agricultural product, Demand and supply linear model was employed. From the supply side, important macroeconomic variables like agricultural product export (AGEX (million US Dollar) which is taken as dependent Variable, GDP of the exporting country, Real Effective Exchange Rate (REER), Openness to trade (OPENN), Foreign Direct Investment (FDI ), Export Diversification Index (DIVER), Landlockdness (LANDLK) were considered. On the other hand from the demand side variables like GDP of the importing country (GDP) of country's trade partners was considered.

All the data were transformed in to log before estimation made. The data was tested for unit root test using LLC test technique, and all data were found to be stationary at level. Before the estimation appropriate model selection was carried out. Accordingly, Breusch and Pagan LM was used for the selection between pooled regression and Random effect, and again Hausman test was used to test between random effect and fixed effect. The selection test result confirmed that random effect to be an appropriate model for the analysis. Findings of the study revealed that from the supply side of LnGDPEXP $_{\text {it }}$, LnEXDIV $_{\text {it, }}$ LnREER $_{\text {it }}$, LnOPENN it $_{\text {it }}$ were found to be statistically significant at $\mathrm{P}<$ 0.01 level, while from the demand side, LnGDP $_{\text {Chinat }}$ variables was found to be statistically significant at $\mathrm{P}<0.01$.

B- P/LM and Pasaran CD (cross -sectional dependence) tests were used to test whether the residuals are correlated across countries. Pasaran $\mathrm{CD}$ test result shows that there is strong statistical evidence to accept the null hypothesis. This indicates that Residuals across entities Countries are not correlated.

\section{References}

Amoro, G. and Shen, Y. 2013. The Determinants of Agricultu ral Export: Cocoa and Rubber on Cote d'Ivoire. Int. J . Econ. Fin. 5(2): 228233.

Bacchetta, M. 2007. Releasing Export Constraints: The Role of Governments, ERSD, WTO. Available online at http:// www.aercafrica.org.documents.exportsupp ly- working-paper.

Baltagi, H.B. 2005. Econometric Analysis of Panel Data: $3^{\text {rd }}$ edn. J ohn Wiley \& Sons Ltd, The Atrium, Southern Gate, Chichester, West Sussex PO19 8SQ, England. 301p.

Baltagi, B.H. 2008. Econometric Analysis of Panel Data. $4^{\text {th }}$ edn. J ohn Wiley \& Sons Ltd., Chichester.

Christiaensen, J. 2004. Toward an understanding of household vulnerability in rural Kenya. World Bank Policy Research Working Paper 3326. Washington, DC: World Bank. 45p.

Gbetnkon, D. and Khan, S.A. 2002. Determinants of agricultural export: The case of Cameroon. The African Economic Research Consortium, Nairobi, Kenya. 45p.

Dramĕ - Yayĕ, A., Chakeredza, S. and Temu, A.B. 2011. Agricultural R\&D: Investing in Africa's Future; Analyzing Trends, Challenges \& Opportunities held in Accra, Ghana on 5-7 December 2011. Gains in Agricultural commodity exports.

Eyayu, T. 2011. Determinants of agricultural export in sub-Saharan Africa using panel data for 47 SSA countries. Evidence from panel data. Addis Abeba University, Ethiopia.

FAO. 2011. Medium - term prospects for Agricultural http:// www.fao.org.

Green, B.F. and Tukey, J.W. 1960. Complex analyses of variance: general problems. Psychometrika. 25(2): 127-152.

Hausman, J.A. 1978. Specification tests in econometrics. Econometrica. 46(6): 1251-71. https:// doi.org/ 10.2307/ 1913827

IMF. 2010. Regional Economic Outlook: SubSaharan Africa, http:// www.imf.org/ external/ pubs/ft/reo/2013/ afr/ eng/sreo0513.pdf last accessed May 22, 2018. 
Kumar, N. and Pradhan, J.P. 2002. Foreign Direct Investment, Externalities and Economic Growth in Developing Countries: Some Empirical Explorations and Implications for WTO Negotiations on Investment. RIS Discussion Papers 27, Research and Information System for the Non-Aligned and Other Developing Countries, New Delhi.

LaMotte, L.R. 1983. Fixed, random, and mixedeffects models. Encyclopedia of Statistical Sciences. pp. 137-141.

Lee, L.F. 2001. Asymptotic distributions of quasimaximum likelihood estimators for spatial econometric models. Mixed regressive, spatial autoregressive processes. Ohio State University.

Levin, C., Lin, F. and Chu, C. 2002. Unit Roots Tests in Panel Data: Asymptotic and Finite Sample Properties. J. Econometrics. 108(1): $1-24$. 4076(01) 00098-7.

Marno, V. 2004. A Guide to Modern Econometrics: $2^{\text {nd }}$ edn., J ohn Wiley \& Sons
Ltd, The Atrium, Southern Gate, Chichester, West Sussex P.O. 19 8SQ, England. 429p.

Mkpado, M. 2013. Some Indicator of African Agriculture Situations, Exports and Opportunities. J . Business Admin. Edu. 3(2): $123-155$.

Omilola, B., Yade, M., Karugia, J. and Chilonda, P. 2010. Monitoring and Assessing Targets of Comprehensive Africa Agricultural Development Program (CAADP) and the First Millennium Development Goal (MDG) in Africa. Regional Strategic Analysis and Knowledge Support System (ReSAKSS) Working Paper 31: 83-85.

Wooldridge, J.M. 2002. Econometric Analysis of Cross Section and Panel Data Cambridge, MA: MIT Press.

World Bank. 2005. World Development Indicators 2005, World Bank Washington, D.C.

World Bank. 2007. World Development Report 2007. Attacking Poverty. New York, Oxford University Press. 